\title{
Het einde van hart- en vaatziekten nabij: Feit of fictie?
}

Citation for published version (APA):

Hofker, M. H. (2000). Het einde van hart- en vaatziekten nabij: Feit of fictie? Universiteit Maastricht. https://doi.org/10.26481/spe.20001207mh

Document status and date:

Published: 07/12/2000

DOI:

10.26481/spe.20001207mh

Document Version:

Publisher's PDF, also known as Version of record

\section{Please check the document version of this publication:}

- A submitted manuscript is the version of the article upon submission and before peer-review. There can be important differences between the submitted version and the official published version of record.

People interested in the research are advised to contact the author for the final version of the publication, or visit the DOI to the publisher's website.

- The final author version and the galley proof are versions of the publication after peer review.

- The final published version features the final layout of the paper including the volume, issue and page numbers.

Link to publication

\footnotetext{
General rights rights.

- You may freely distribute the URL identifying the publication in the public portal. please follow below link for the End User Agreement:

www.umlib.nl/taverne-license

Take down policy

If you believe that this document breaches copyright please contact us at:

repository@maastrichtuniversity.nl

providing details and we will investigate your claim.
}

Copyright and moral rights for the publications made accessible in the public portal are retained by the authors and/or other copyright owners and it is a condition of accessing publications that users recognise and abide by the legal requirements associated with these

- Users may download and print one copy of any publication from the public portal for the purpose of private study or research.

- You may not further distribute the material or use it for any profit-making activity or commercial gain

If the publication is distributed under the terms of Article $25 \mathrm{fa}$ of the Dutch Copyright Act, indicated by the "Taverne" license above, 


\title{
Het einde van hart- en vaatziekten nabij: Feit of fictie?
}

\author{
Prof. dr. Marten H. Hofker
}

Rede uitgesproken bij de aanvaarding van het ambt van Hoogleraar in de Moleculaire Genetica aan de Faculteit Geneeskunde van de Universiteit Maastricht op donderdag 7 december 2000 
Hierbij wil ik graag Margreet Staal bedanken voor de taalkundige ondersteuning en Wilma Claessen voor de totstandkoming van deze gedrukte versie. 


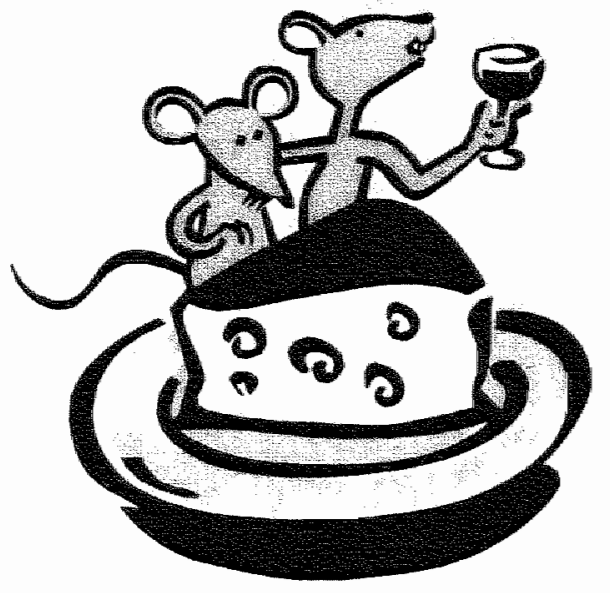


Mijnheer de Rector Magnificus,

Zeer gewaardeerde toehoorders,

Van alle kennis die we nu hebben over het functioneren van ons lichaam, met name over het functioneren van onze genen, is het merendeel de afgelopen tien jaar beschikbaar gekomen. Vandaag hoop ik u duidelijk te maken wat dat voor ons gevecht tegen hart- en vaatziekten kan betekenen. Ik zal u schetsen welke wegen wij met ons onderzoek in Maastricht zullen gaan, en waar wij uiteindelijk op uit hopen te komen.

Mijn uitgangspunt voor deze rede is de genetica. Het jaar 2000 is voor de genetica een heel bijzonder jaar. Het is precies 100 jaar geleden dat de wetten van Mendel herontdekt zijn door drie botanici; één van hen was de Nederlander Hugo de Vries. De wetten van Mendel beschrijven de grondbeginselen van de genetica, waaronder het principe dat eigenschappen als onafhankelijke eenheden kunnen overerven. Deze eenheden kennen we nu als genen. Onafhankelijke overerving betekent dat als een persoon met donker haar een erfelijke ziekte heeft, dat niet wil zeggen dat alle personen met donker haar automatisch ook dezelfde erfelijke ziekte zullen hebben. Onafhankelijke overerving vindt plaats, ondat onze genen verdeeld zijn over verschillende chromosomen. Als we de geslachtschromosomen niet meetellen, hebben wij 22 paar chromosomen. Het hebben van 2 kopieën van ieder gen leidt tot de verhouding 1 staat tot 2 staat tot 1 voor homozygoten en heterozygoten, zoals in 1865 al door Mendel beschreven werd.

De wetten van Mendel gelden niet alleen voor de duidelijk herkenbare eigenschappen. Iedere variatie in ons DNA laat een Mendeliaans verervingspatroon zien. Een klein deel van deze variatie zal betrokken zijn bij ziekten. Het grootste deel hiervan zal geen speciale betekenis hebben en is neutraal. Het is bekend dat ten minste 1 wan elke 1000 DNA baseparen variatie vertoont. Tussen individuen kunnen dus 3 miljoen verschillen bestaan.

\section{Het koppelingsonderzoek}

Deze variatie in het DNA heeft inmiddels zijn toepassing gevonden bij het maken van DNA profielen voor vaderschapstesten en forensisch 
onderzoek. Verreweg de belangrijkste toepassing is echter het koppelingsonderzoek. Hiermee kan worden vastgesteld of iemand zelf drager is van een ziekte-mutatie, de kans heeft op een kind met een erfelijke aandoening. Deze tweede toepassing werd al in 1937 voorzien door Haldane and Bell. Ruim voordat er ook maar iets bekend was over de structuur van onze genen en chromosomen, stelden zij het volgende: If "to take a possible example, an equally close linkage" (as between the genes for hemophilia and color blindness) "were found between the genes for bloodgroup" and that "determining Huntington's chorea, we should be able, in many cases, to predict which children of an affected person would develop this disease and to advise on the desirability or otherwise of their marriage". Dus, indien wij weten welke "neutrale" kenmerken gekoppeld met een bepaalde ziekte overerven, dan kunnen wij aan de hand van deze kenmerken voorspellen of iemand de ziekte zal krijgen. De koppeling tussen een ziekte en een neutraal kenmerk is het gevolg van het feit dat sommige eigenschappen dicht bij elkaar op het zelfde chromosoom liggen en daardoor juist niet meer onafhankelijk overerven. Neemt deze afstand op het chromosoom toe, dan wordt de kans op de gekoppelde overerving snel kleiner. Het idee van Haldane was zijn tijd ver vooruit, want men beschikte destijds niet over voldoende kennis orn het idee van koppelingsonderzoek in praktijk toe te passen.

De algemene toepassing van koppelingsonderzoek werd pas mogelijk, toen variatie in ons DNA zichbaar gemaakt kon worden. Met behulp van DNA analysetechnieken ontdekte men dat de hoeveelheid variatie enorm groot was. Op basis hiervan werd in 1980 door Botstein en collega's voorgesteld om een complete genetische kaart van de mens te maken. Hiermee zouden in principe alle erfelijke eigenschappen in kaart gebracht kunnen worden en lag de weg open om de genetische oorzaken van erfelijke ziekten te vinden. Zo werd al in 1983 een DNA-marker gevonden waarmee de zojuist genoemde ziekte van Huntington in families kon worden gevolgd.

\section{Het humane genoomproject}

Het in kaart brengen van het humane genoom was echter een gecompliceerde onderneming. Dat kan ik uit de praktijk onderschrijven. Als promovendus was ik actief betrokken bij de ontwikkelingen in het humane genoomonderzoek. Onder leiding van Prof. Peter Pearson 
hielden wij ons in Leiden bezig met het opsporen van DNA-fragmenten, waarmee variatie in DNA kon worden aangetoond. Dit was een dankbare onderneming. In 1985 leidde dit onderzoek al tot de allereerste prenatale diagnose op basis van DNA-markers. Dit onderzoek aan de spierziekte van Duchenne werd destijds uitgevoerd door Prof. Bert Bakker. De eerste complete genetische kaart van de mens kwam beschikbaar in 1988. Rond die tijd werden ook de contouren zichtbaar van een nog groter plan, namelijk het genereren van de sequentie van het volledige humane genoom. In 1989 werd definief besloten om dit onderzoek grootscheeps aan te pakken. Het zogenaamde humane genoom project was geboren. Uiteindelijk mondde dit uit in een wereldwijde inspanning, waarbij zowel de academische onderzoeksgemeenschap, als de industrie er hard aan getrokken heeft om dit mega-project te realiseren. Dankzij de onderlinge rivaliteit tussen deze twee onderzoeksgemeenschappen zijn uiteindelijk de geplande tijdschema's ruimschoots gehaald en zal de sequentie begin komend jaar worden gepubliceerd in een van de vaktijdschriften.

Ik wil twee technische ontwikkelingen noemen die essentieel gebleken zijn bij de totstandkoming van het humane genoom project. Ten eerste de PCR-reactie. Deze werd in 1985 ontwikkeld door de Nobel-laureaat Kary Mullis. Met behulp van de PCR reactie kunnen we ongelimiteerd DNA kopiëren. Uitgaande van slechts één DNA-molecuul kan een grote hoeveelheid worden gemaakt. Niemand had 15 jaar geleden kunnen voorspellen wat deze simpele proef zou gaan betekenen voor de moleculaire genetica. lk kan mij nog goed herinneren dat Prof. Gert-Jan van Ommen onmiddellijk na het verschijnen van het eerste artikel hierover, dit in onze wekelijkse bijeenkomst besprak. De werkelijke impact van deze techniek was op dat moment nog lang niet voor iedereen duidelijk. Duurde de opheldering van een mutatie in een gen voorheen vaak enkele maanden, met behulp van PCR is er soms niet meer dan een dag voor nodig. Dankzij PCR is er ook minder uitgangsmateriaal nodig. Een wanguitstrijkje levert al voldoende DNA op om uitgebreid genetisch onderzoek te doen. Ook op andere terreinen heeft de PCR het moleculairgenetisch onderzoek vereenvoudigd en nieuwe mogelijkheden verschaft. Denkt u daarbij maar aan het forensisch onderzoek waarbij één haar voldoende kan zijn om een dader aan te wijzen. De PCR heeft definitief de weg vrijgemaakt voor "high throughput" genoomanalyse. Dit is niet alleen essentieel voor het sequencen op grote schaal, maar ook voor de genetische analyse van complexe erfelijke aandoeningen. 
Ten tweede wil ik de ontwikkelingen noemen in de informatietechnologie, zoals het beschikbaar komen van krachtige PC's en Internet. Het gereed komen van de volledige humane genoomsequentie stelt emorme eisen aan informatieverwerking. Het is geen kleinigheid om van de naar schatting 60 miljoen benodigde fragmenten van 500 DNA-basen één geheel te kunnen maken, dat uiteindelijk bestaat uit 24 verschillende chromosomen met een gezamenlijke lengte van 3 miljard basen. Vooral als $u$ beseft, dat ons DNA niet alleen bestaat uit de unieke sequenties die onze genen coderen, maar ook uit repetitieve sequenties. Deze repetitieve DNA-fragmenten hebben steeds dezelfde sequentievolgorde. Aangezien we de functie van deze fragmenten nog niet goed kennen, wordt dit ook wel junk-DNA genoemd. Het in elkaar passen van deze 60 miljoen fragmenten komt dus qua problematiek overeen met een legpuzzel die voor meer dan de helft uit blauwe lucht bestaat! Als deze puzzel klaar is, zal de complete DNA-sequentie als zodanig nog heel weinig toegankelijk zijn woor de gemiddelde moleculair bioloog. Eerst moet de plaats van duizenden genen worden vastgesteld. Vaak zal de DNA-sequentie alléén onvoldoende aanknopingspunten bieden voor verder onderzoek. Daarom zijn er ook catalogi nodig met de vermelding van alle genen en hun onderlinge relaties. Veel genen en onderdelen van genen lijken op elkaar. Op basis van deze overeenkomsten worden voorspellingen gemaakt over hun functie.

Naast de informatie over genen zal de humane genoomsequentie ook goed inzicht geven in de genetische variatie van de mens. Op dit moment zijn er al meer dan 2 miljoen verschillen in het DNA gevonden. Het Internet is van essentieel belang om al deze informatie voor iedereen toegankelijk te maken. Wereldwijd zijn er data bestanden ontstaan, die niet alleen informatie over de genoomsequenties en al onze genen bevatten, maar ook de biologische informatie uit de vakliteratuur. De mogelijkheid om deze databestanden met elkaar te vergelijken stelt ons in staat de relaties tussen genen, genetische variatie, biologische processen en ziekten met elkaar in verband te brengen.

\section{Erfelijke ziektes}

De activiteiten die door het humane genoomproject wan de grond kwamen, hebben het genetisch onderzoek enorm gestimuleerd. De afgelopen 15 jaar zijn de genetische oorzaken van honderden erfelijke 
aandoeningen opgehelderd. Hierbij gaat het voornamelijk om de zogenaamde monogene erfelijke aandoeningen. Dit zijn aandoeningen waarbij één gen dat keurig volgens de wetten van Mendel overerft, de hoofdrol speelt. Het zijn vaak zeer ernstige aandoeningen, maar ze zijn gelukkig ook erg zeldzaam. Ongeveer tweederde van alle mensen zal echter overlijden ten gevolge van genetische ziekten, die niet lijken over te erven volgens de wetten van Mendel. Tot deze categorie van ziekten behoren de chronische aandoeningen en ouderdomsziekten, waaronder ook hart- en vaatziekten. We vinden geen keurig overervingspatroon omdat bij dit soort ziekten meerdere genen tegelijk betrokken zijn. Bovendien zijn deze aandoeningen gevoeliger voor niet-genetische invloeden, die door de omgeving worden bepaald. Het doorgronden van de genetische basis van deze aandoeningen is de uitdaging voor de komende decennia.

\section{Hart-en vaatziekten}

Daarmee ben ik dan terug bij de titel van mijn verhaal. Vandaag hoop ik u duidelijk te maken welke rol de genetica zal gaan spelen bij het ontrafelen van hart- en vaatziekten. Hart- en vaatziekten zijn "volksvijand nummer één", en maken in Nederland per jaar ongeveer 50.000 slachtoffers. Ondanks de verbeterde behandelmethoden zal dit aantal de komende jaren niet afnemen. Ten dele komt dit door de vergrijzing van de bevolking. Daarnaast zien we nog steeds geen afname van een aantal belangrijke risicofactoren zoals roken en slechte eetgewoonten. Daarom trok de publicatie van Goldstein en Brown in 1996 in het gezaghebbende tijdschrift Science zeer veel aandacht. Deze publicatie was getiteld: Heart attacks, gone with the century? Met andere woorden: is de oplossing van dit vraagstuk binnen bereik?

\section{Cholesterol}

We zallen eerst stilstaan bij het werk van Goldstein en Brown aan het cholesterolmetabolisme, waarvoor zij in 1985 de Nobelprijs hebben ontvangen. Cholesterol is één van de belangrijkste bouwstenen van de cel, en wordt op grote schaal aangemaakt door het lichaam zelf. Het is een bouwstof voor bijnier- en geslachtshormonen, en speelt een essentiële rol bij de structuur van celmembranen. De van cholesterol afgeleide galzuren zijn essentieel voor de opname van vetten in de darm. 


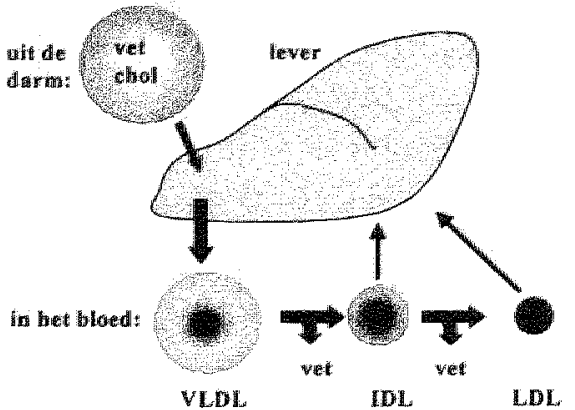

Figuur I A: Normaal metabolisme

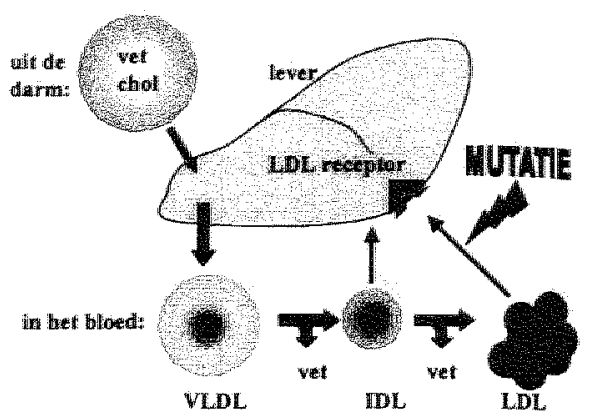

Figuur $1 \mathrm{~B}$ : Mutatie in de LDL receptor

Cholesterol en vet lossen echter niet in water op en zullen dan ook niet zomaar in de bloedbaan getransporteerd kunnen worden. Cholesterol wordt daarom verpakt in vetrijke deeltjes. $\mathrm{Na}$ een maaltijd zal vrijwel al het vet en cholesterol dat door de darm wordt opgenomen binnen 2 uur de lever bereiken (Figuut 1 A). In de lever worden andere deeltjes gemaakt, die voor een verdere verdeling van cholesterol en vet in het lichaam zorgen. In eerste instantie zijn dit grote deeltjes, die VLDL genoemd worden. Naarmate het vet eruit verdwijnt, worden ze kleiner en cholesterolrijker. Uiteindelijk wordt het een LDL-deeltje. De meeste LDL-deeltjes worden vervolgens door de lever opgenomen en gedeeltelijk via de gal weer uitgescheiden. Daarnaast bestaan er ook HDL-deeltjes. Het HDL ruimt overtollig cholesterol uit het lichaam op en brengt het naar de lever terug. VLDL en LDL vormen het zogenaamde "slechte" cholesterol. Deze deeltjes kunnen gemakkelijk aan de vaatwand blijven plakken, en dan aderverkalking veroorzaken. Het HDL daarentegen is het goede cholesterol en voorkomt juist aderverkalking. Cholesterol speelt dus een cruciale rol bij aderverkalking, die op zijn beurt weer de hoofdoorzaak van hart-en vaatziekten is.

Hoewel de meesten van u zullen denken dat het merendeel van het cholesterol via het voedsel wordt opgenomen, is dat onjuist. Cholesterol wordt met name door het lichaam zelf gemaakt. Op het moment dat een cel te weinig cholesterol heeft, zal deze het zelf gaan aanmaken. 


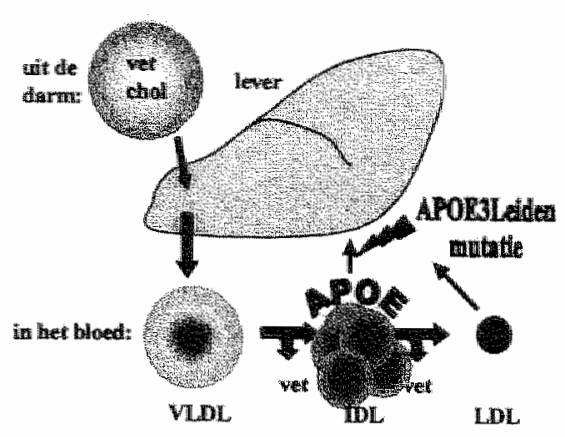

Figun 1:

A) laat een diagram zien van het cholesterol metabolisme zoals dat normaalgesproken verloopt.

B) geeft de situatie weer, die ontstatial bij een mutatie in het LDL receptor gen. Het aantal LDL deeltjes zal dan sterk toenemen.

C) geef aan dat als gevolg van een APOE mutatie de VLDL remnants (IDL) niet meer goed worden opgenomen.

Figuar $1 \mathrm{C}$ : Mutatie in APOE

Tegelijkertijd neemt iedere cel ook cholesterol op uit het bloed via de circulerende LDL-deeltjes. Hoewel vrijwel alle cellen cholesterol kunnen opnemen, is de lever hiervoor het meest gespecialiseerd. Daarmee is de lever het meest belangrijke orgaan om de juiste cholesterolwaarden in het lichaam te handhaven. Verkeerde diëten kunnen de eigen aanmaak van cholesterol stimuleren, waardoor de cholesterolspiegel in het bloed stijgt.

\section{Statines}

Op basis van dit inzicht in het cholesterolmetabolisme zijn de zogenaamde "statines" ontwikkeld. Statines verhinderen dat cholesterol aangemaakt wordt in de cel. Omdat een cel well over voldoende cholesterol moet kunnen blijven beschikken, neemt deze vervolgens extra efficiënt cholesterol op uit het bloed. Hierdoor daalt de cholesterolspiegel in het bloed sterk.

Statines zorgen daarmee vooral voor een daling van het slechte cholesterol, het LDL. Grote klinische studies hebben inmiddels het gunstige effect van de statines bewezen: Statines reduceren zowel het LDL-cholesterol, het aantal hartaanvallen, als ook de sterfte, met ongeveer $30 \%$. De grafiek die ik vertoon (op de volgende pagina) laat de relatie zien tussen de cholesterolspiegel in het bloed en de frequentie van hart- en vaatziekten 
Deze getallen zijn gebaseerd op een studic in mensen met een ziektegeschiedenis. Het gat om personen die al een keer eerder een hartinfarct hebben gehad, of een veel te hoge cholesterolspiegel

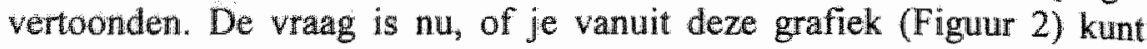
extrapoleren en kunt voorspellen wat er gaat gebeuren als de gemiddelde LDL-cholesterolspiegel verder daalt. Als dat mogelijk is, dan zou een werdere verlaging van de LDL-cholesterolspiegel in het bloed een groot effect hebben op de frequentie van hart-en vaatziekten in de populatie. Het idee van Goldstein en Brown is, dat als de risicogroep cerder gediagnostiseerd kan worden, er veel vroeger dan nu gebruikelijk is met het verstrekken van statines zou moeten worden begonnen. Hierdoor zou het risico op hart-en valziekten zo sterk terug lopen, dat het geen "volksvijand nummer éen" meer zou zijn aan het begin van deze eeuw.

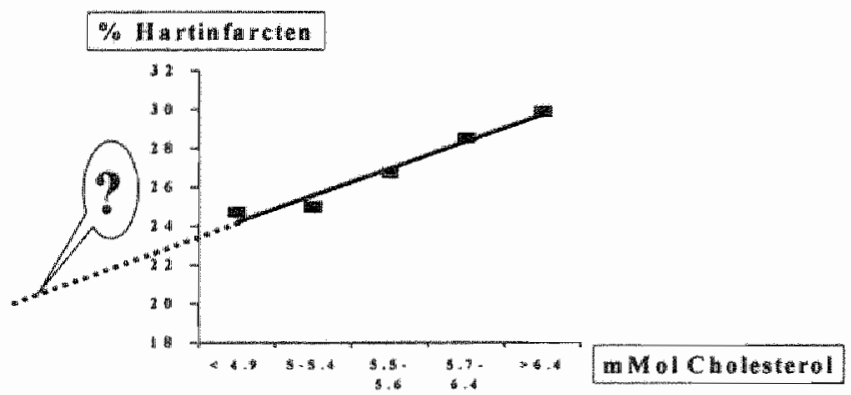

Figuur 2: Relatie tussen de plasma cholesterol spiegel en het woorkomen van hartinfracten (Sachs e.a. Circulation, 102:1893-1900)

Belang van een wroege diagostiek bij hart-en vaatziekten

Niemand zal bestrijden dat het inzicht in het cholesterolmetabolisme en de ontwikkeling van de statines grote wetenschappelijke doorbraken zijn. Wel is er veel kritiek gekomen op de optimistische verklaring van Goldstein en Brown. Dit komt omdat wereldwijd het vóórkomen van hart-en vaatziekten sterk toeneemt.

In de westerse wereld vanwege de vergrijzing, en in de overige landen vanwege de introductie van de westerse leefstijl. Het is maar zeer de vraag of deze toename door middel van statines gekeerd kan worden. Immers, de getallen uit de trials waar Goldstein en Brown hun optimisme aan ontlenen zijn gebaseerd op patiênten, die een eerste hartaanval hebben overleefd. In feite zijn we daarmee al te laat. Liever zouden we 
mensen op tijd herkennen, zelfs vóór de eerste aanwijzingen van hart- en vaatziekten. Vraag is: hoe herkennen we deze mensen?

\section{Rol van genetische factoren}

We weten dat het grootste risico op het krijgen van hart- en vaatziekten genetisch bepaald is. Gebleken is namelijk dat het hebben van een eerste graads bloedverwant met een hart- en vaataandoening de sterkste risicofactor is woor het ontwikkelen van de ziekte. Sorns is thet risico heel goed voorspelbaar, omdat hart- en vaatziekte als een monogene eigenschap overerft. De meest bekende aandoening is familiaire hypercholesterolemie. In dit geval is er een mutatie in het LDL-receptor gen (Figuur 1 B). Normaal gesproken neemt de LDL-receptor het slechte LDL-cholesterol op uit het bloed. Een mutatie in de LDL-receptor kan dit proces verstoren, hetgeen leidt tot een verhoging van het LDL. Daarnaast kan ook het APOE-eiwit, één van de bestanddelen van VLDL en IDL, gemuteerd zijn (Figuur $1 \mathrm{C}$ ). Het APOE zorgt ervoor dat het VLDL en IDL aan de LDL-receptor kunnen binden. Een mutatie in het APOE-gen kan tot gevolg hebben dat de VLDL-en IDL-deeltjes niet meer goed uit het bloed worden opgenomen. Uiteindelijk leidt dit tot een ophoping van vet en cholesterol in het bloed.

De zojuist genoemde monogene aandoeningen zijn van fundamenteel belang geweest om de relatie tussen gen en ziekte te kunnen begrijpen. Deze aandoeningen zijn echter zeer zeldzaam en zullen geen verklaring zijn voor de doorsnee patiënt met hart- en vaatziekten. In het algemeen vertoont de aanleg voor hart- en vaatziekten een veel complexer overervingspatroon, waarbij meerdere genen en omgevingsfactoren betrokken zijn. Dit maakt het een stuk moeilijker om de onderliggende genetische factoren op te sporen. Dit is goed te illustreren aan de hand van de volgende stamboom (Figuur 3). In deze famille zijn twee mensen, namelijk een zoon en een kleinkind, overleden aan de gevolgen van harten vaatziekten. De eerste vraag die hierbij opkomt is: Hebben zoon en kleinkind dezelfde genetische factoren die bepalend waren voor de ziekte? In veel gevallen zal dit een vraag zijn waarop nu nog geen antwoord mogelijk is. Vrijwel elke patiënt zal een unieke combinatie van meerdere genetische en omgevingsfactoren hebben die tot ziekte heeft geleid. Voor hart- en vaatziekten kennen we nu al minstens honderd genen die een rol kunnen spelen, en dit aantal zal alleen maar toenemen. 


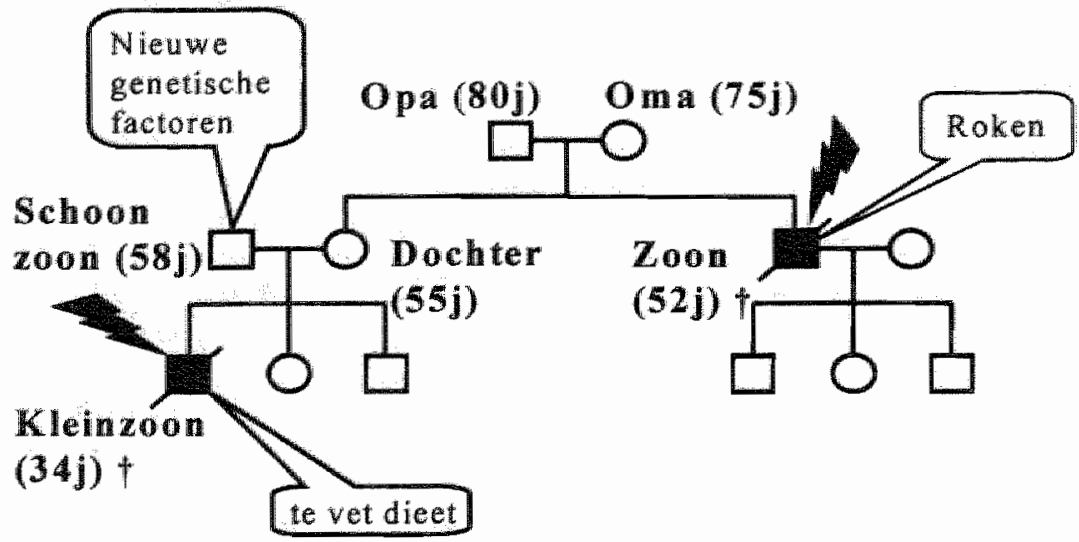

Figuur 3: Complexe owererving van hart- en vaatziekten

Daarnaast is de interactie tussen genen en omgeving van belang. Zo zijn er aanwijzingen dat bepaalde genetische variatie de gevoeligheid voor bijvoorbeeld roken of vetrijke voeding beinvloedt en daardoor de kans op ziekte werhogen.

\section{Transgene muismodellen}

Om deze complexe interactie tussen genen en omgevingsfactoren beter uit te zoeken subsidieerde de Nederlandse Hartstichting in 1992 een voorstel ingediend door de professoren Rune Frants, Louis Havekes, en mijzelf. In die subsidie-aanvraag stelden wij voor deze interactie niet in mensen te bestuderen maar gebruik te maken van transgene muizen. Dat klinkt tegenwoordig heel gewoon, maar in die tijd stond de muis door zijn afwijkende vetmetabolisme en zijn geringe afmetingen, bekend als een onbruikbaar model voor hart- en vaatziekten. Dankzij de transgene modellen veranderde de reputatie van de muis echter snel.

Wij hebben aan dit succes bijgedragen door de APOE3Leiden muis te ontwikkelen. Deze transgene muis draagt het menselijke APOE-gen met de zogenaamde APOE3Leiden-mutatie, waardoor het APOE niet meer goed kan functioneren. Het gevolg hiervan is, dat het VLDL en IDL langzamer uit het bloed worden opgenomen. 


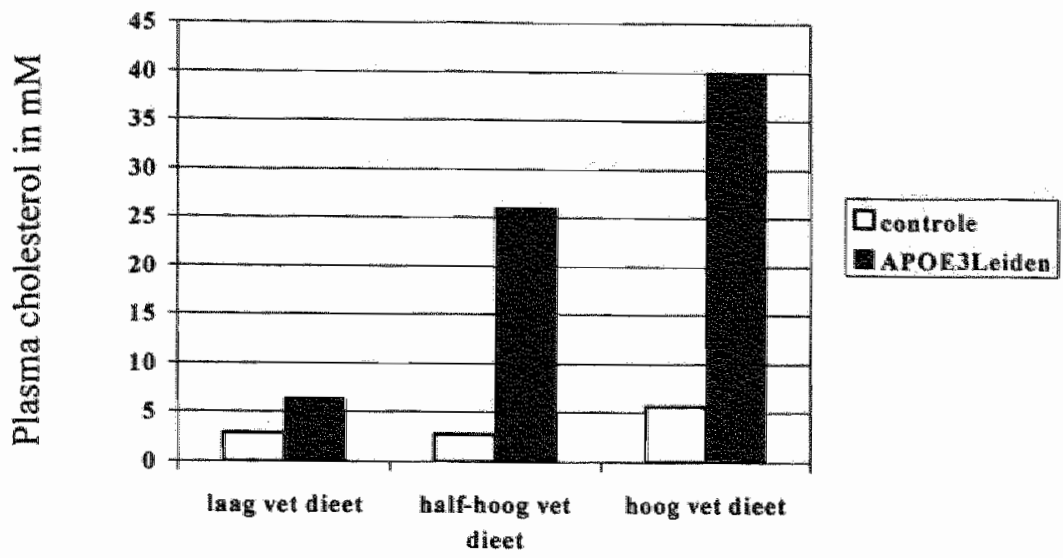

Figurur 4: Invloed van het dieet op de plasma cholesterol waarden van de APOE3Leiden muis

Door de aanwezigheid van het APOE3Leiden transgen lijkt de vetstofwisseling van de muis meer op die van de mens.

Tevens bleken de APOE3Leiden-muizen heel erg gevoelig te zijn geworden voor een vetrijk dieet (Figuur 4). Normaal muizenvoer bevat $4 \%$ vet. Verhoging van het vet in het voer tot $15 \%$ leidt in gewone muizen slechts tot een geringe stijging van de cholesterolspiegel. De APOE3Leiden-muizen daarentegen laten een veel sterkere stijging van de cholesterolspiegel zien. Bovendien leidt dit vetrijke dieet in de APOE3Leiden-muizen tot een verhoogde gevoeligheid voor aderverkalking. Overigens noemen wij dit dieet het zogenaamde "western type diet" vanwege z'n grote gelijkenis met ons dagelijkse voedsel qua vetsamenstelling.

Met deze achtergrond zal ik u mijn toekomstplannen schetsen. Mijn onderzoek zal zich langs twee hoofdlijnen ontwikkelen.

De ene hoofdlijn is gericht op het ontsluiten van de genoominformatie. De vraag is: Welke genen spelen een rol bij hart- en vaatziekten? Vanuit de eerste onderzoekslijn zullen we veel genen ontdekken waarvan de functie onbekend is.

De tweede hoofdlijn richt zich op het uitzoeken van de functie van deze genen. Met een multidisciplinair team gaan wij de infrastructuur creëren om het ziekte proces van gen tot functie te bestuderen. 
Het genoomonderzoek zal in nauwe samenwerking met Leidse onderzoekers, in het bijzonder Dr. Corina Moen, worden voortgezet. Het uitgangspunt van dit onderzoek wordt gevormd door muizen genetica, wat ons voorbij de huidige grenzen van de humane genetica kan brengen. Genetisch onderzoek bij mensen kent een aantal beperkingen. Tussen verschillende personen zullen de ongevingsfactoren meestal niet gelijk zijn. Zelfs binnen één persoon zal de omgeving, waaronder rookgewoonte, voeding en lichaamsbeweging, variabel zijn. De gemiddelde familie is klein, en bestaat vaak uit niet meer dan twee à drie generaties. Bovendien is de genetische variatie zo groot, dat de mogelijke gencombinaties vrijwel onbeperkt zijn. Bij muizen is dit anders. Wij kunnen zelf bepalen wat de leefomstandigheden van de muizen zijn. De muizen bevinden zich in een zeer schone omgeving zonder ziektekiemen en we kunnen nauwkeurig de aard en hoeveelheid van de voeding bepalen. Bovendien kan een muizenfamilie zich in een half jaar enorm ontwikkelen. Zoals u zult begrijpen hebben we hier geen last van een te klein aantal generaties of nakomelingen. De fokprogramma's kunnen we zelf bepalen. Daarmee hebben we een uitstekende controle op de genetische factoren die we willen bestuderen. Door de nakomelingen van een ouderpaar herhaaldelijk met elkaar te kruisen zijn honderden ingeteelde stammen ontstaan. Binnen een ingeteelde muizenstam zijn alle nakomelingen identiek, zodat de individuele genetische variatie enorm is terug gebracht. Tussen verschillende muizenstammen kunnen de verschillen wel groot zijn. Wij hebben een aantal van de ingeteelde stammen gebruikt om de APOE3Leiden-muizen te voorzien van verschillende genetische achtergronden. Het resultaat was, dat de verschillende muizen een grote variatie in hun cholesterolspiegels lieten zien, omdat ze verschillend reageerden op een vetrijk dieet. Omdat de omgevingsfactoren constant gehouden waren, moet dit verschil dus een genetische basis hebben. De verantwoordelijke genen zullen we de komende tijd ophelderen aan de hand van een aantal grote muizenfamilies. Met deze informatie kunnen we dan weer terug naar de mens, aangezien het muizengenoom en het humane genoom grote gelijkenis vertonen. Zo kunnen we kijken of deze genen ook bij de mens betrokken zijn bij hart- en vaatziekten. Indien dit het geval is, zal zo'n gen een goede kandidaat zijn voor de ontwikkeling van diagnostiek, preventie en farmacotherapie voor hart- en vaatziekten. Het zal duidelijk 
zijn dat dit soort projecten door het beschikbaar komen van de DNAsequentie en de genenkaart van muis en mens in een stroomversnelling zijn geraakt.

Het geneticaonderzoek is een goed voorbeeld van phenotype gedreven onderzoek: je ziet een eigenschap, en je gaat vervolgens op zoek naar het gen. Als je dit gen te pakken hebt, weet je de functie nog niet, maar je weet al wel het belangrijkste: dit gen speelt een rol bij hart- en vaatziekten! Om de functie van het nieuw ontdekte gen verder in kaart te kunnen brengen, moeten we de onderzoekslijn omkeren; we beginnen met een bepaald gen, genereren een transgene muis, en stellen vervolgens de vraag of deze muis hart- en vaatziekten krijgt. Om deze proef goed te doen zouden we natuurlijk graag willen beschikken over een aan-uit knop en een volumeregelaar voor dit gen. De technieken om transgene muizen te genereren zijn inmiddels zo geavanceerd, dat dit kan. We kunnen ervoor zorgen dat het gen alleen in een bepaald orgaan en op een bepaald moment zal werken.

\section{Aderverkalking}

Wij gaan de transgene muizen onder meer inzetten om de vraag te beantwoorden hoe het komt dat een verhoogde cholesterolspiegel hart- en vaatziekten veroorzaakt.

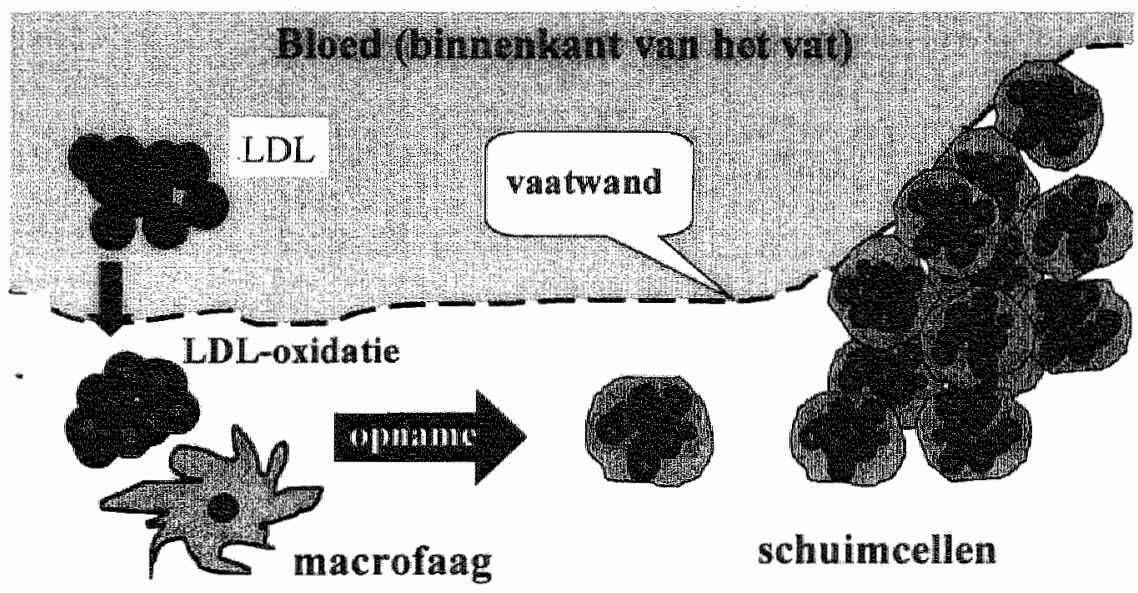

Figuur 5: LDL als drijvende kracht van schuimcelvorming en Atherosclerose: 
Naar aanleiding van wat ik $u$ eerder heb verteld, zult $u$ denken dat we daar alles over weten. Helaas is dit niet het geval. De meeste kennis is namelijk gebaseerd op studies in een reageerbuis, en de vertaling naar een situatie in het lichaam klopt lang niet altijd. Wel weten we dat bij het ontstaan van aderverkalking macrofagen een prominente rol spelen (Figuur 5).

Macrofagen zijn cellen die het lichaam op orde proberen te houden door alle rotzooi op te ruimen. Zo komen ze ook in actie bij het opruimen van het slechte LDL cholesterol, wanneer dat aan de vaatwand blijft plakken. Deze macrofagen eten zich letterlijk klem in de vaatwand, en veranderen daardoor in schuimcellen, waardoor het begin van aderverkalking ontstaat.

\section{Oxidatie en antioxidatie}

De rol van het slechte LDL-cholesterol bij aderverkalking was aanvankelijk onduidelijk, omdat in de reageerbuis LDL niet door macrofagen kan worden opgenomen. We weten inmiddels dat LDL eerst moet veranderen voordat macrofagen het opnemen. De verandering van LDL komt tot stand door oxidatie en enzymatische modificatie. Er zijn veel studies in proefpersonen gedaan om de rol van antioxidanten, zoals bijvoorbeeld vitamine $E$, bij het voorkómen van aderverkalking te onderzoeken. Het zou immers schitterend zijn, als u door vitamine $E$ te slikken de komende feestdagen uw bescherming tegen aderverkalking zou kunnen opvoeren. Helaas zijn de resultaten van de vitamine E-studies niet eenduidig. I $\mathrm{k}$ kan $\mathrm{u}$ dus niet beloven dat bepaalde vitamines en voedingsmiddelen met antioxidanten het proces van aderverkalking kunnen remmen.

Eén van de onderliggende fundamentele vragen met betrekking tot de rol van antioxidanten is, of het werkelijk doelmatig zou zijn om de vorming van geoxideerd $L D L$, en dus de opname van $L D L$ door macrofagen af te remmen. Recent is er een gen ontdekt, dat betrokken is bij de opname van geoxideerd LDL. Deze ontdekking bood de mogelijkheid het proces van schuimcelvorming te beïnvloeden en daarmee de rol ervan bij aderverkalking te ontrafelen. Dr. Menno de Winther heeft daartoe transgene muizen gemaakt. Deze muizen hebben macrofagen die in de reageerbuis sneller het geoxideerde LDL opnemen en daardoor sneller in schuimcellen veranderen. Je denkt dan, dat deze muizen sneller 
aderverkalking zullen krijgen, maar tot onze verbijstering waren deze muizen opeens beschermd tegen aderverkalking!

Deze proef roept onmiddellijk de vraag op, of je nu well of niet moet verhinderen dat macrofagen het vaatwand-LDL opnemen. Doen ze het wel dan ontstaan er schuimcellen die de eerste aanzet zijn tot aderverkalking. Maar wat gebeurt er als de macrofagen het $L D L$ niet opnemen? Blijkbaar hoopt het LDL zich op in de vaatwand en kan zo ook aanleiding geven tot aderverkalking. Wij moeten deze resultaten zien te verklaren, door een beter inzicht te krijgen in de rol van de macrofaag in samenhang met zijn "omgeving". De reageerbuis is in dit geval niet voldoende. Het zou mij niet verbazen als we er straks achter komen dat de macrofaag onder één bepaalde conditie de vaatwand schoon kan houden, en dus helpt aderverkalking te voorkomen. (In dat geval helpen antioxidanten niet, indien zij de opname van LDL door de macrofaag tegen gaan). Bij de andere conditie is er zoveel cholesterol, dat de macrofaag het niet meer kan verwerken en dan zouden antioxidanten het ontstaan van schuimcellen kunnen vertragen. Hoewel we nog heel veel vragen hebben, illustreert dit gedachte-experiment dat het gebruik van sommige middelen, zoals bijvoorbeeld vitamine $\mathbb{E}_{\text {, alleen baat zou }}$ kunnen hebben bij de juiste doelgroep, en bij de overige personen zelfs schadelijk zou kunnen zijn.

\section{Gemoomonderzoek}

Ik heb maar een heel klein deel van het ontstaan van hart- en vaatziekten kunnen verduidelijken, omdat wij bij ons onderzoek de processen gewoonlijk in kleine stappen opdelen. Dankzij het humane genoomproject is er een geheel ander type onderzoek ontstaan, dat wordt aangeduid met de term "genoomonderzoek". Hierbij proberen we een reeks momentopnames te maken van de cel, waarbij duizenden gegevens tegelijkertijd worden geregistreerd (Figuur 6 en 7). De betekenis van het genoomonderzoek wordt op dit moment hoog ingeschat. Is dat wel terecht? Momenteel weten we namelijk van slechts $5 \%$ van de genen globaal de functie. Voor de genen betrokken bij hart- en vaatziekten zal dit niet beter zijn, en dus zijn we op zoek naar vele honderden genen. Denk aan een auto, waar we slechts enkele onderdelen van kunnen benoemen. Je vraagt je dan af hoe hij zou kunnen rijden. Nu denken we zelf, dat we al een heel goed idee hebben hoe onze auto rijdt omdat we de 
buitenkant goed kennen. Hetzelfde geldt voor hart- en vaatziekten. Immers, veel van de hart- en vaatziekteprocessen worden bepaald door eiwitten, die gemakkelijk te vinden zijn omdat ze een rol spelen in het bloed. Wat voor soort genen ontbreken er dan nog? Een belangrijke categorie genen die tot nu toe buiten beeld gebleven is, betreft de regel genen: In autotermen: het gaspedaal zie je wel, maar wat er gebeurt als je dit gaspedaal indrukt, besef je niet.

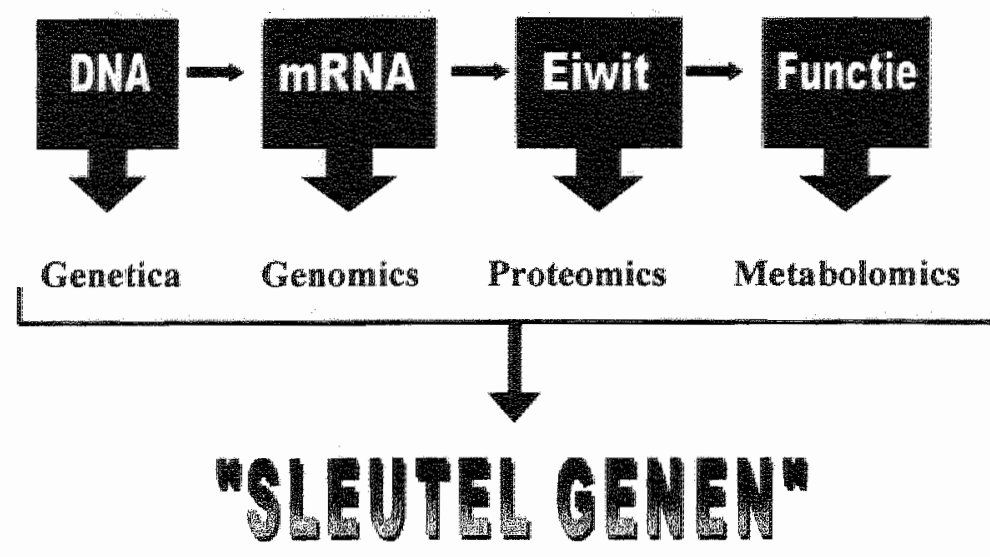

Figuur 6: De verschillende niveaus van modem "high troughput" onderzoek

Genen zorgen voor de productie van eiwitten die uiteindelijk de gewenst functies uitvoeren. Omdat een levercel er anders uitziet dan een hersencel, zult $u$ begrijpen dat niet alle genen altijd mogen aanstaan.

Waar veel belangstelling naar uitgaat zijn de regelmechanismen, die bepalen hoeveel en wanneer er bepaalde eiwitten worden gemaakt. Dankzij het humane genoomproject is er nu een methode die het mogelijk maakt om van alle genen tegelijkertijd vast te stellen of ze actief zijn. Daarmee is het dus mogelijk te bepalen welke groepen genen tegelijkertijd worden aan of afgezet. Op basis van deze gecoördineerde regulatie kunnen we voorspellen welke genen bij een bepaald proces actief worden en er dus mee te maken kunnen hebben. Ook het onderliggende genregulatie-netwerk, met eventuele links tussen verschillende processen kan ermee worden opgehelderd. Op deze manier krijgen we aanwijzingen welke genen met een tot nog toe onbekende 
functie voor ons onderzoek interessant kunnen zijn. Hiervoor worden de zogenaamde DNA chips, of microarrays gebruikt. Dit zijn glaasjes met duizenden verschillende genen. In ons eigen onderzoek kijken we bijvoorbeeld welke genen aan staan in de lever, zodat we een goed idee kunnen krijgen wat er allemaal in beweging wordt gezet na de toediening van een bepaalde voedingscomponent of van een medicijn.

Een vraag die bij veel mensen leeft is, om hoeveel genen het bij de mens gaat, die we tegelijkertijd met de chips in de gaten willen houden. Deze vraag zal hopelijk snel beantwoord kunnen worden, omdat de humane genoomsequentie zo goed als af is. Momenteel lopen de schattingen uiteen van 27.000 tot 80.000 . Het aantal genen zal alleen niet weergeven, hoeveel eiwitten er vervolgens gemaakt kunnen worden. Het is bijvoorbeeld bekend dat het 900-cellige micro-aaltje, C. elegans, over meer genen beschikt dan het veel ingewikkeldere fruitvliegje. Dit fruitvliegje heeft echter een extra truc: het kan namelijk in een aantal gevallen van een gen twee of meer verschillende eiwitten maken. Voor de mens geldt dit principe ook. Het aantal genen zegt dus niet veel over het aantal eiwitten dat gemaakt kan worden.

\section{Genetisch onderzoek}

(families)

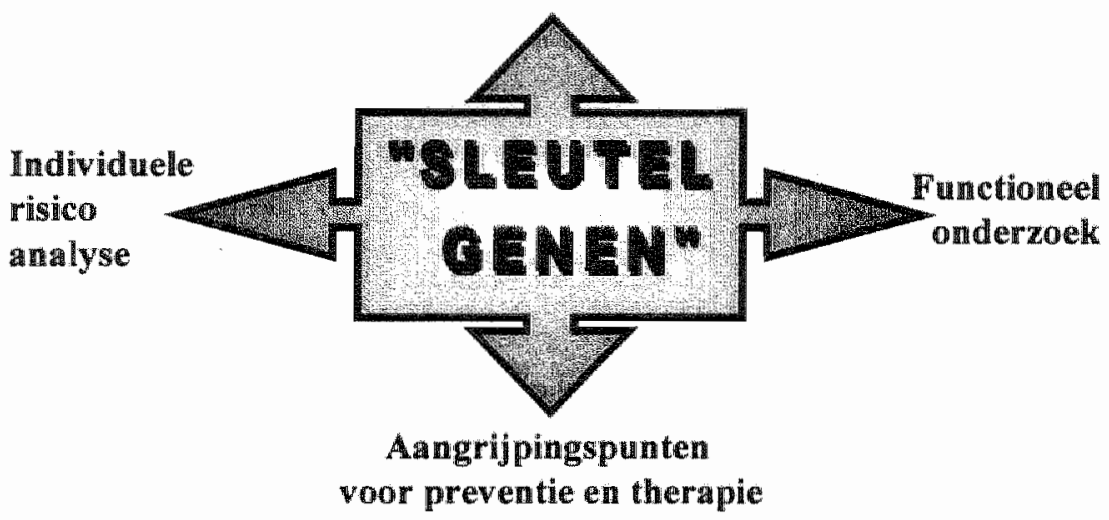

Figuur 7: De rol van (moleculair) genetisch onderzoek

De biologie is zelfs nog ingewikkelder! Als voorbeeld noem ik het apolipoproteine E. Dit eiwit speelt een hoofdrol bij de stofwisseling van cholesterol en vetten. Enkele mutaties in dit gen veroorzaken een sterk 
verhoogde lipidenspiegel in het bloed. Echter, er is ook een mutatie in dit gen bekend, die verantwoordelijk is voor de ziekte van Alzheimer. Ondanks onze gedetailleerde kennis over de functie van APOE bij het wetmetabolisme, hebben we geen idee hoe APOE betrokken kan zijn bij Alzheimer. Daarmee is het dus duidelik dat een eiwit meerdere functies kan hebben, en daardoor ook betrokken kan zijn bij total verschillende ziekten.

Als een gen verschillende ziekten kan veroorzaken, hoe zit het dan met de rol van hetzelfde gen bij verschillende organismes? We hebben inmiddels kunnen zien, dat hier juist verrassend veel samenhang bestaat. Ik vertelde $u$ al over het succes van de muismodellen bij het bestuderen van hart- en vaatziekten. Dit succes is te danken aan het feit dat de lipidengenen bij muis en mens vrijwel hetzelfde functioneren. Dus wat we leren bij de muis is verbazingwekkend vaak van toepassing op de mens. Het meest opmerkelijke voorbeeld hiervan is dat genen die voor het lichaamsbouwplan wan het fruitvliegje coderen, in een aantal gevallen zelfs kunnen worden uitgewisseld met die van de muis met behoud van functie. Het is de verwachting, dat naarmate de genoomprojecten hun voltooiing naderen, de overstap tussen de verschillende modelorganismen steeds gemakkelijker zal worden.

De verwachtingen over de microarray-studies zijn mijns inziens terecht hoog gespannen. Hetzelfde concept kan worden toegepast op alle eiwitten in een cel, en wordt proteomics genoemd. Ook op het niveau van de chemische stoffen komt er "metabolomics" onderzoek. De grote belofte van dit genomics onderzoek is de mogelijkheid verbanden tussen processen in kaart te brengen.

\section{Rol van genetisch onderzoek}

Tijdens mijn rede heb ik de rol van cholesterol bij hart- en vaatziekten uitvoerig beschreven. Dit is een belangrijke invalshoek om het ziekte proces te leren begrijpen, en ik heb deze gekozen omdat ik hiermee een aantal onderzoeksprincipes aan de hand van het eigen onderzoek heb kunnen toelichten.

Andere belangrijke risicofactoren zijn: hoge bloeddruk, diabetes en thrombose. Het genomics-onderzoek zal beter dan ooit op moleculair 
niveau de verbanden kunnen aangeven tussen deze verschillende ziekteprocessen. Genomics zal dus gebruikt worden om de verschillende cellulaire processen in zijn totaliteit te beschrijven. Het is wel een opname als een luchtfoto vanuit de space-shuttle. Details zullen ontbreken. Daarvoor moeten we terugkeren op aarde. Daar zullen we op zoek blijven naar de zogenaamde "sleutel-genen" (Figuur 6 en 7). Belangrijke genen die ons houvast kunnen geven als gereedschap bij de genetische studies, en die als aangrijpingspunt kunnen dienen bij het zoeken naar geneesmiddelen.

Uiteindelijk ligt het hart van de bioloog toch bij de individuele genen. Als elk gen even ingewikkeld is als APOE, levert dit voldoende leuk onderzoek op. Wel is ons beeld van een genfunctie totaal veranderd, en denken we veel meer aan de rol van genen als onderdelen van een systeem. We hebben oog voor de verschillende taken die een gen kan hebben, en de interactie van het gen met $z^{\prime} n$ omgeving. Het onderzoek met behulp van transgene muizen komt volledig tegemoet aan de wens genfunctie op de verschillende niveaus te kunnen bestuderen en daarmee de processen in de mens beter te begrijpen.

Het inzicht in de DNA-variatie is enorm toegenomen door het genoomproject en zal van onschatbare waarde zijn voor het genetisch onderzoek. Daarmee kom ik op het gebied van de populatiegenetica, dat door Prof. Bob Vlietinck zal worden uitgevoerd. Naast het genoomonderzoek is genetisch onderzoek bij de mens essentieel om straks klinisch relevant inzicht in de complexe ziekten te krijgen. Uiteindelijk zal dit genetisch onderzoek de diagnostische mogelijkheden moeten opleveren, waarmee inzicht wordt verkregen in het individuele risico op hart- en vaatziekten, en vervolgens de optimale methoden voor preventie en behandeling bij een bepaald individu. Deze individuele geneeskunde is de belofte voor de toekomst. Een belofte die door het genoomproject heel dichtbij gekomen is.

\section{Genetische geneeskunde}

Rest mij de vraag, wanneer hart- en vaatziekte geen "volksvijand nummer één" meer zal zijn. Dit is beslist geen fictieve vraag. Op grond van de ontwikkelingen van het biomedisch onderzoek in de afgelopen 20 jaar durf ik met zekerheid te zeggen, dat het veel eerder een feit zal zijn dan u en ik denken. 
De eeuw van de genetische geneeskunde is dit jaar definitief aangebroken. Ik wil u dus vragen daar nu al rekening mee te houden. Dat vergt veel educatie. Allereerst zal de vooruitgang van onze fundamentele kennis in evenwicht moeten blijven met de klinische behoeften en mogelijkheden. Op de lange termijn moet de individuele vraag naar de kans op hart- en vaatziekten er een worden voor de huisarts. Immers, je wilt niet alle gezonde mensen met een grotere kans op hart- en vaatziekten in het ziekenhuis laten komen. Dat zijn er te veel. Om de betrokkenheid van huisartsen bij de genetische diagnoses en ziektepreventie realiteit te kunnen laten worden, is het nu nodig daar tijdens de algemene opleiding tot arts aandacht aan te schenken.

\section{Voeding}

Wanneer nu een risico op hart- en vaatziekten wordt geconstateerd, krijgt men vaak preventief een statine voorgeschreven. Op zich heb ik daar geen problemen mee. Wanneer men echter kan kiezen tussen levenslang pillen slikken of gezonder eten, dan zal meestal de voorkeur uitgaan naar een betere voeding. Juist dit gebied is volop in beweging. Er is echter nog zeer veel onderzoek nodig om de meest interessante voedingscomponenten te identificeren. Ik sluit mij dan ook aan bij het recente artikel in de Consumentengids, waarin om een betere onderbouwing van de gezondheidsclaims van bepaalde voedingsmiddelen wordt gevraagd. Het is voor de consument momenteel onvoldoende duidelijk welke gezondheidsclaims op wetenschappelijk bewijs gebaseerd zijn. Eén van de gunstige uitzonderingen zijn Benecol en Becel proactief. Aan de introductie ervan is zeer veel onderzoek voorafgegaan. Ook de APOE3Leiden-muis heeft zijn maaltijden ermee gehad en de gezondheidsclaims verder onderbouwd. Deze margarines bevatten fytosterolen. Dit zijn natuurlijke stoffen uit de houtindustrie en voorkómen de cholesterolopname in de darm. Het is een voorbeeld van een "functional food", dat het cholesterolgehalte in het bloed verlaagt. Het zou natuurlijk prachtig zijn, als mensen de keus zouden hebben uit een reeks "functional foods" en daarnaast bij de drogist een testje kunnen kopen, om het effect ervan zelf te kunnen vaststellen.

De inbedding van mijn hart- en vaatziekte onderzoek in het CARIM en NUTRIM staat er voor garant, dat het onderzoek de volledige 
bandbreedte zal kunnen beslaan van kliniek tot en met functional foods. Dankzij de brede onderzoeksstrategie, de BOS, zal de komende jaren een genetica-afdeling tot stand komen, waarin de belangrijkste aspecten verenigd zullen zijn. Hierbij gaat het om moleculaire genetica, populatie genetica, klinische genetica en functionele genetica. Daarbinnen wordt onder meer met steun van het onderzoeksinstituut Groei en Ontwikkeling de transgene faciliteit opgericht. Momenteel zijn er plannen om de zwaartepunten op het gebied van het genoomonderzoek verder uit te bouwen, via het oprichten van een nieuwe studie door de Universiteit Maastricht en het Limburgs Universitair Centrum te Diepenbeek. Gezien de schaalvergroting van het modern biomedisch onderzoek is dit een noodzakelijke ontwikkeling om de door de BOS ingezette impuls uit te bouwen tot een sterk onderzoekscentrum. Ik hoop dan ook dat dit plan slaagt, en er voldoende extra middelen voor onderzoek zullen komen. Als onderzoeker heb ik het gevoel dat ik niet slechts aan het begin van een nieuwe taak sta, maar dat er ook een nieuw tijdperk is aangebroken voor het biomedisch onderzoek.

\section{Onderzoeksbeleid in Nederland}

De dynamiek in het onderzoek is sterk toegenomen, en onderzoekers moeten snel kunnen inspelen op nieuwe ontwikkelingen. Kenmerkend is de duurdere apparatuur, en het zogenaamde "high throughput" onderzoek. Helaas zijn er in Nederland te weinig financiële middelen in vergelijking met de ons omringende landen. Decennia van verwaarlozing van de loopbaanperspectieven van academici gaan hier hun tol eisen. Dieptepunt was de invoering van de beurspromovendus, die goedkoper kon zijn. Bovendien kwam dat op een moment dat de eerste tekenen van krapte op de arbeidsmarkt zich aandienden. De sterke verwaarlozing van het Nederlandse onderzoek was, na de laatste Prinsjesdag, aanleiding tot de publicatie wan een kritisch artikel in het gezaghebbende Amerikaanse tijdschrift Science. Er wordt gewaarschuwd dat zonder beleidswijzigingen de toppositie van het Nederlandse onderzoek niet meer gehandhaafd zal blijven. De verwachting is dat er een tekort aan arbeidskrachten zal ontstaan dat oploopt tot 3000 in 2003 . Het is een somber beeld, dat gelukkig niet speelt in de gehele EU. Hopelijk kan daar in Maastricht voordeel mee gedaan worden, omdat het door zijn ligging bij uitstek geschikt is om buiten de landsgrenzen goed gekwalificeerde onderzoekers aan te trekken. Verder dienen zich de eerste geluiden aan, 
dat cok de Nederlandse politici beseffen dat fundamentele wetenschap een onmisbaar onderdeel van onze kennismaatschappij is. Ondanks mijn kritische noot, ga ik met wertrouwen de toekomst tegemoet.

\section{Dankwoord}

Bij deze wil ik graag degenen bedanken, die betrokken zijn bij de oprichting van de nieuwe onderzoeksgroep. Allereerst gaat mijn dank voor het in mij gestelde vertrouwen uit naar het College van Bestuur, het bestuur van de Faculteit Geneeskunde en de directeuren van de onderzoeksinstituten CARIM, NUTRIM en GROW.

De professoren Struijker Boudier en Geraedts zijn de afgelopen anderhalf jaar steeds mijn eerste aanspreekpunt geweest.

Beste Harry, met jouw brief is mijn Maastrichtse avontuur begonnen. Voor jouzelf markeert het de stap van vakgroepsvoorzitter naar directeur van het CARIM. Ik ben er van overtuigd dat de leiding van het CARIM bij jou in uitstekende handen is, en ik kan nu wel vertellen dat dit het besluit makkelijker gemaakt heeft de grote stap van Leiden naar het verre Maastricht te maken.

Beste Joep, vanaf het begin heb ik het gevoel gehad dat het goed klikte. In 1983 had jij al de wens de genetica van hart-en vaatziekten onder de loep te nemen, want het bestuderen van monogene aandoeningen was klaar, en de complexe genetica was het volgende probleem. Regeren is vooruit zien. Ik heb het vertrouwen dat jij mij met deze vooruitziende blik langs de Maastrichtse klippen zal loodsen, zodat ik mijn tijd aan de wetenschap kan blijven besteden.

Verder ben ik blij dat ik mijn rede heb kunnen uitspreken in de aanwezigheid van een groot aantal collega's uit Leiden, die vanaf 1982 voor mij de perfecte onderzoeksomgeving hebben gecreëerd. Ik kan hiervan slechts enkele mensen noemen:

\section{Prof. Pearson}

Beste Peter, als promoter heb jij mij al in een vroeg stadium tot een zelfstandig onderzoeker laten ontwikkelen. Kenmerkend voor jou is de openheid en duidelijkheid waarmee jij jouw mening geeft. Deze instelling is volgens mij essentieel voor degenen die de wetenschap vooruit willen 
helpen, en ik ben er dankbaar voor, dat ik dit algemene principe van jou heb kumnen leren.

\section{Prof. van Ommen}

Beste Gert-Jan, met jouw nationale en internationale bekendheid heb jij de Leidse afdeling Humane Genetica op de wereldkaart gezet. Jouw vindingrijkheid leidde tijdens mijn promotie-onderzoek tot veel suggesties, waarvan ik door tijdgebrek slechts een deel heb kunnen opvolgen. Na het vertrek van Peter heb jij op voortreffelijke wijze de leiding van de afdeling op je genomen. Ondanks de sterk toegenomen grootte van de afdeling, heb je de eenheid ervan goed weten te behouden en de onderzoekscultuur op een uitstekende manier vorm gegeven.

\section{De professoren Frants en Havekes}

Ik wil jullie bedanken voor de fantastische steun die jullie mij hebben geboden. Vanaf het KNAW fellowship dat jullie tijdens mijn verblijf in Canada hadden aangevraagd tot nu, heb ik altijd alle mogelijkheden gekregen om mijn eigen koers uit te zetten.

Beste Rune, in 1985 zijn wij via Prof. Eduard Klasen met elkaar in contact gekomen, en dat is zeer vruchtbaar gebleken. Mijn oratie is er het beste bewijs voor, dat er steeds succesvolle samenwerkingen in jouw onderzoeksgroep ontstonden, waarbij de genetica, de kliniek en functioneel onderzoek hand in hand gingen. Hopelijk betekent de nu gerealiseerde samenwerking tussen Leiden en Maastricht op het gebied van de genetica, dat wij elkaar kunnen blijven versterken.

Beste Louis, jij was de tweede peiler onder mijn Leidse bestaan. Door allerlei formaliteiten had de samenwerking tussen TNO en de Universiteit heel moeilijk kunnen zijn, maar jij lette erop dat het tegendeel waar werd. Zonder problemen konden alle onderzoekers hun proeven doen in de verschillende laboratoria, en deskundig advies was altijd dichtbij. Verder hebben we zoveel gezamenlijke projecten geschreven en gekregen, dat ik inmiddels niet meer besef, dat ik deze kunst eerst van jou moest leren.

\section{Dr. Willems van Dijk}

Beste Ko, jouw werk aan de adenovirus gemedieerde genexpressie heeft onze lipidengroep zeer competitief gemaakt. Daar ben ik je zeer erkentelijk voor, want door deze ondersteuning zijn de meeste AIO's bij ons op tijd gepromoveerd. Ook menig artikel promoveerde zo naar een beter blad. Met mijn vertrek is een deel van mijn werkzaamheden op 
jouw schouders terechtgekomen. Ik ben er van overtuigd dat daarmee de continuiteit van de Leidse onderzoeksgroep gewaarborgd is.

Alle andere personen van de Leidse hart- en vaatziekten groep, waaronder, Hans Princen, Bart van Vlijmen, Miek Jong, Paul Tacken, en Andre van der Zee; Ik zou het wel willen, maar het lukt mij niet meer om jullie individueel te noemen. Mijn dank is er echter niet minder om.

Een aantal collega's is met kennis en ervaring meeverhuisd naar Maastricht. Menno de Winther, Patrick van Gorp, Marion Gijbels en Monique Vergouwe; Zonder jullie had ik het hier wellicht niet kunnen redden. Bedankt voor het vertrouwen waardoor jullie besloten om de grote stap naar Maastricht samen met mij te zetten. Een heel nieuw begin is voor niemand makkelijk, maar als ons lab rond de zomer klaar is wordt dat bopelijk snel anders.

\section{Corina Moen en Arja Kreeft}

Voor jullie was de stap toch net iets te groot. Ik heb het erg op prijs gesteld, dat jullie ondanks alles de experimenten goed hebben kunnen voortzetten. Wij hebben nu een samenwerkingsprogramma opgezet waarvan ik hoop dat dit een groot succes zal gaan worden. Het is geen gernakkelijke tijd geweest, maar ik ben er van overtuigd dat wij een hoop leuke momenten voor de boeg zullen hebben, want jullie genoomonderzoek heeft op alle fronten de wind in de zeilen.

Graag wil ik ook de Nederlandse Hartstichting noemen.

Ik ben de NHS zeer erkentelijk voor de persoonsgerichte steun, die ik de afgelopen 4 jaar heb mogen ontvangen. Ik heb mij daardoor helemaal op hart- en vaatziekten kumnen en durven concentreren, en dat lijkt nu hopelijk voor beide partijen - z'n vruchten af te werpen.

Tenslotte wil ik mijn ouders bedanken voor het al vroeg stimuleren van mijn biologische interesse. I $\mathrm{k}$ beschouw het als een groot voorrecht dat jullie deze dag kunnen meemaken.

\section{Lieve Cisca,}

Het hebben van een partner waarbij je terecht kunt met alles, dus ook de wetenschappelijke vragen, is een voorrecht dat moeilijk in woorden valt te beschrijven. Toen de mogelijkheid van Maastricht langs kwam, heb je 
nooit aan jezelf gedacht. Ik ben je ook erkentelijk voor de geweldige steun die je hebt geboden tijdens de voorbereidingen van deze dag, en kijk er naar uit om de feestdagen te benutten om onze gezamenlijke aandacht weer eens op iets anders te richten.

Ik dank u voor uw aandacht,

Ik heb gezegd 